\title{
Pinyon-juniper chaining and seeding for big game in cen- tral Utah
}

J.G. SKOUSEN, J.N. DAVIS, AND J.D. BROTHERSON

\section{Abstract}

Vegetation and soils were evaluated on 5 different-aged, mechanically treated and seeded pinyon-juniper sites and compared to adjacent untreated areas. Plant cover was significantly changed after treatment: trees were reduced from 26 to $6 \%$ total ground cover; shrubs were increased from 2 to $8 \%$ ground cover; and herbaceous plants increased from 2 to $13 \%$ ground cover. Annuals and perennial forbs were $75 \%$ of the total plant cover on the 2-year-old site, perennial grasses and shrubs dominated the plant cover (52 to $83 \%$ ) on three, 14- to 20-year-old sites, while shrubs and trees combined for $84 \%$ of the plant cover on the 24-year-old site. Two Agropyron grass species showed good establishment and persistence after seeding. Seeded forbs contributed about $5 \%$ of the total plant cover on the 2-year-old treated site and they declined on older treated sites. Seeding of shrubs was only successful on sites where the shrub species was already present in the understory naturally. Seeding of nonnative shrub seed did not produce stands. Even though tree cover was reduced after treatment, total tree density was not. Shrub density increased from an average of 800 plants/ha on untreated areas to 2,750 plants/ha on treated areas. Juniper mortality during mechanical treatment varied from 60 to $91 \%$ and was related to the percentage of trees estimated to be $60+$ years old $(r=0.97)$ and with the number of trees greater than $5 \mathrm{~cm}$ in stem diameter $(r=0.71)$ on the adjacent untreated sites. Big game pellet group counts were not different between untreated and treated sites, suggesting that big game make use of these treated areas because of increased forage and browse and in spite of reduced security cover.

Key Words: revegetation, tree mortality, woodland structure, pioneer species, competition

The pinyon-juniper (Pinus spp.-Juniperus spp.) woodland type covers from 17 to 32.5 million ha in the southwestern United States (Kuchler 1964, West et al. 1975). More than 25\% of Utah's land area is dominated by pinyon-juniper, which often suppresses growth of understory shrubs, grasses, and forbs. Big game populations in Utah use the pinyon-juniper type extensively for winter range (Plummer et al. 1968). During the severe winter of 1948-1949, poor winter range contributed to losses of up to $42 \%$ in some deer herds, while other deer herds with good winter range had losses comparable to those occurring during a moderate winter. Because of such losses the Utah Division of Wildlife Resources in cooperation with the USDA Forest Service's Intermountain Research Station initiated a program to improve depleted big game winter range. Such improvements involved mechanical tree removal and artificially seeding adapted grass, forb, and shrub species to increase forage production (Plummer 1958, Plummer et al. 1960,

At the time of the research, authors were biological aid and research wild life biologist, Utah State Division of Wildlife Resources, Shrub Sciences Laboratory, Intermountain Research Station, Forest Service, U.S. Department of Agriculture, Provo 84601; and professor, Department of Botany and Range Science, Brigham Young University, Provo 84602 . Current address for J.G. Skousen: Division of Plant and Soil Sciences, West Virginia University, Morgantown 26506.

This research was made possible with Federal funds for wildlife restoration provided through Pittman-Robertson Project W-82-R, Job 1 , in cooperation with the Intermountain Research Station, USDA Forest Service, and the Utah Division of Wildlife Resources.

Manuscript accepted 15 September 1988.
1968, 1970).

Average tree kill with cabling or chaining ranges from 40 to $80 \%$ (Arnold et al. 1964, Aro 1971, 1975, Parker 1971). In the Great Basin, Phillips (1977) noted that chaining reduces tree overstory by nearly $100 \%$ and that the majority of trees observed on chained areas are those that survived the chaining. There is little evidence on most sites of rapid invasion by young trees establishing from seed (Stevens 1987). Reduction of tree cover by mechanical methods reduces competition for light, soil nutrients, and moisture (O'Rourke and Ogden 1969) and stimulates understory browse and grass growth (Arnold et al. 1964, Phillips 1977, Plummer et al. 1968). An early study in Utah (Plummer et al. 1970) estimated that total understory production before treatment of several pinyonjuniper sites was $22 \mathrm{~kg} / \mathrm{ha}$. Ten years after 2-way chaining and seeding with 4 grasses and 3 legumes, total production increased to $1,912 \mathrm{~kg} / \mathrm{ha}$ on grazed areas and $1,717 \mathrm{~kg} / \mathrm{ha}$ on ungrazed areas.

Despite increases in forage production, some problems associated with pinyon-juniper treatment for big game include: (1) a 5-to 10-year rejuvenation period before some of the slower growing browse species become available; and (2) loss of security cover for big game animals if large open tracts of land (greater than $250 \mathrm{~m}$ wide) are treated. In an attempt to alleviate such problems researchers recommend clearing small, localized areas, or long, narrow, contoured strips from 30 to $200 \mathrm{~m}$ in width and seeding desirable species in the openings (Minnich 1969, Phillips 1977, Short et al. 1977, Short and McCulloch 1977).

The objectives of this study were to evaluate: (1) plant species composition and cover changes between treated and adjacent untreated sites; (2) seeded species establishment and growth on treated areas; (3) mechanical treatment effects on woody plant densities; and (4) the consequences of these changes in relation to big game use. Because differences existed between sites, the study examined similarities and general trends of vegetation change in response to mechanical treatment and seeding, and the influence that management may have had on treated sites.

\section{Study Sites}

The areas selected for study are along the western benches of the Pahvant Mountains in Millard County and on the Wasatch Plateau in Sanpete County in central Utah. The Utah Division of Wildlife Resources owns 4 of the study sites. These were treated specifically to increase forage and browse production for big game. A 5th site (Nine Mile) is privately owned and was treated to improve forage production primarily for sheep.

Elevation, aspect, slope, and precipitation were similar on these sites (Table 1). Soils had a thin, light-colored surface horizon, underlain by a subsurface horizon of weathered parent material derived from limestone, sandstone, and shale. The soils were moderately calcareous with $\mathrm{pH}$ ranging from 6.5 to 7.5 . Soil textures were sandy loams, loams, and clay loams.

Vegetation cover before treatment consisted of pinyon pine (Pinus edulis Engelm.), Utah juniper (Juniperus osteosperma (Torr.) Little), Gambel oak (Quercus gambelii Nutt.), and infrequent and scattered grasses, forbs, and shrubs in the understory 
(Plummer et al. 1970). Native shrubs that occurred in woodland openings were big sagebrush (Artemisia tridentata Nutt.), black sagebrush (Artemisia nova A. Nels), true mountain mahogany (Cercocarpus montanus Raf.), bitterbrush (Purshia tridentata (Pursh) DC.), cliffrose (Cowania mexicana D. Don), and broom snakeweed (Gutierrezia sarothrae (Pursh) Britt. \& Rusby). Browse species had been overgrazed by livestock and big game and were in a state of low vigor at the time of treatment (Plummer et al. 1970). Cheatgrass (Bromus tectorum L.) was typically the most prominent understory species.

Mayfield, Nine Mile, Corn Creek, and Hilltop were chained 1-way, aerially seeded, then chained in the opposite direction in the late fall of $1960,1967,1967$, and 1979, respectively, with $41 \mathrm{~kg}$ chain links (Table 1). The Pioneer site was first seeded, then cabled 1-way in October 1957. Cabling was used on this site because large numbers of big sagebrush and cliffrose were present in the understory and this method does less damage to these desirable understory species than chaining (Plummer et al. 1968). Seeded species and seedling rates are shown in Table 2 along with their relative cover on each treated site in 1981.

Management policy of the Utah Division of Wildlife Resources is to graze rehabilitated big game winter ranges with cattle during the spring to reduce grass and forb cover, thereby enhancing browse production for wintering big game. Grazing animal and stocking rate varied among the sites studied (Table 1).

\section{Sampling Methods}

Study sites were sampled during July and August of 1981 along 4 randomly located transects of $300 \mathrm{~m}$ each that were placed perpendicular to the edge of treated areas. One half, or $150 \mathrm{~m}$, extended into the native, untreated woodland and $150 \mathrm{~m}$ into the treated area. Quadrats $\left(1 \mathrm{~m}^{2}\right)$ were placed at $5-\mathrm{m}$ intervals (240 quadrats per site) along the transect to estimate total ground cover by plants and individual plant species cover. A modified Daubenmire (1959) technique with 7 cover classes was used to estimate vegetation cover. Relative cover of different plant life forms and seeded species was calculated as a percent of total ground cover by plants for each untreated and treated area on each site.

Density of trees and shrubs was evaluated by using $50-\mathrm{m}^{2}$ circular plots. The enlarged plot was centered on every 3rd quadrat along the transect ( 80 plots per site). Every shrub and tree within the plot was identified and its stem diameter measured at $10 \mathrm{~cm}$ above ground. The largest stem of each shrub was measured if it had multiple stems.

Stem diameters were related to tree age by regression analysis after cutting and counting the growth rings of 20 different-sized juniper trees on each untreated and treated site. These trees were cut near the transects on each site. One growth ring was taken to equal 1 year's growth. Juniper mortality was calculated by estimating the age of the trees (by their measured stem diameter). We assumed the juniper density and age structure was the same between untreated areas and treated areas (before the treatment was applied). Those trees on the treated area that were estimated to be older than the length of time since treatment were considered to have survived the mechanical treatment. Those trees that were estimated to be younger than the length of time since treatment were those that were assumed to reinvade the site by seed. Juniper mortality was determined by calculating the density of trees in the untreated area that were present when the mechanical treatment was done and comparing it to the density of trees older than the length of time since treatment on the treated area.

Relative big game use of these areas was estimated by counting pellet groups within the enlarged plot. A pellet group was counted when a minimum of 15 pellets were found together and when the group was determined to be from the current year (Ferguson 1955).
Some investigations have reported problems with pellet group counts as an index to mule deer habitat preferences (Collins and Urness 1981, Neff 1968). Nevertheless, due to time and survey money constraints of this study, pellet group data were used to estimate and compare relative big game use on untreated vs treated areas.

Soil samples were taken after vegetation sampling was completed to a depth of $25 \mathrm{~cm}$ at every 10 th quadrat (16 samples per site) to determine if vegetational differences were related to soil factors. Soil samples were analyzed for 10 nutrients. Phosphorus, $\mathrm{K}, \mathrm{Ca}, \mathrm{Mg}$, and $\mathrm{Na}$ were extracted by ammonium acetate, while $\mathrm{Zn}, \mathrm{Fe}, \mathrm{Mn}$, and $\mathrm{Cu}$ were determined with DTPA-TEA (Black 1965). Percent N (Kjeldahl method), soil texture (hydrometer method), and $\mathrm{pH}$ ( $\mathrm{pH}$ electrode on 1:1 soil:water paste) were also determined.

Vegetation and soil data were analyzed by analysis of variance to determine significant differences for these parameters on untreated and treated areas across all sites. Duncan's multiple mean comparison test was used to determine significant differences across sites on the untreated and treated sites (Steel and Torrie 1980).

\section{Results and Discussion}

\section{Species Composition and Relative Cover}

With few exceptions, plant life form composition (annual grasses and forbs, perennial grasses, perennial forbs, shrubs, and trees) on untreated areas was relatively similar for all sites (Table 3). Trees contributed most of the cover while annuals, grasses, forbs, and shrubs were present in small amounts. Total ground cover by plants on untreated areas averaged $31 \%$ with about $90 \%$ of that ground cover accounted for by tree canopies.

Relative cover of the different plant life forms changed significantly on treated sites when compared to adjacent untreated areas (Table 3). Added together, relative cover of annuals and perennial forbs was $75 \%$ on the 2-year-old treated site but decreased to less than $15 \%$ on older treated sites. This concurs with Tausch and Tueller (1977) and' ottlers (Barney and Frischknecht 1974, Tausch 1973) who reported annuals and perennial forbs, dominate treated sites for 1 to 2 years following treatment with gradual replacement by grasses, shrubs, and trees. The annual and perennial forbs (e.g., Descuriana sophia (L.) Webb, Bromus tectorum, Verbascum thapsus L., Verbena hastata L., Viguiera ciliata (Robins. and Greenm.) Blake) observed on our 2-year-old treated site were weedy species that invade quickly after soil disturbance.

Perennial grasses and shrubs dominated the 14- to 20-year-old treated sites (Nine Mile, Corn Creek, and Mayfield). Shrub cover was significantly greater on treated compared to untreated areas and tended to increase as the length of time since treatment increased. The Pioneer site (24-year-old, cable-treated site) supported the greatest shrub and tree cover and lowest perennial grass cover compared to any other site. The cable did not disturb the shrub and tree components as much as double-chaining. Therefore, shrub expassion and tree development may have hindered grass establishment on this site. Our records show limited livestock grazing on Pioneer during the 20 years after treatment, but it is possible that grazing pressure reduced grass cover from 1978 through 1981. Cattle were present on the site when vegetation sampling was conducted. The relative amount of cover contributed by trees on these sites was reduced from 87 to $22 \%$ after treatment. Actual ground cover by trees on treated sites ranged from $0.5 \%$ on the 2-year-old chained site to $18 \%$ on the 24-year-old cabled area.

\section{Establishment of Seeded Species}

Relative cover of seeded species varied across the sites from $15 \%$ on the 2-year-old site to $72 \%$ on the 21-year-old site (Table 2). Crested wheatgrass (Agropyron cristatum (L.) Gaertn.) was found 
Table 1. Summary of characteriatics of 5 study sites in central Utah.

\begin{tabular}{|c|c|c|c|c|c|}
\hline \multirow[b]{2}{*}{ Characteristic } & \multicolumn{5}{|c|}{ Study site } \\
\hline & Pioneer & Mayfield & Corn Creek & Nine Mile & Hilltop \\
\hline Elevation (m) & 1770 & 2010 & 1680 & 1950 & 1920 \\
\hline Aspect & SW & Sw & $\mathbf{W}$ & SW & Sw \\
\hline Ave slope (\%) & 6 & 12 & 9 & 8 & 10 \\
\hline Ave precip (cm) & 37 & 32 & 35 & 32 & 33 \\
\hline Range site class & Upland stoney loam & Upland stoney loam & Upland stoney loam & Upland shallow loam & Upland shallow loam \\
\hline Year treated & 1957 & 1960 & 1967 & 1967 & 1979 \\
\hline Treatment method & Cabled and seeded & $\begin{array}{l}\text { Double-chain and } \\
\text { seeded }\end{array}$ & $\begin{array}{l}\text { Double-chain and } \\
\text { seeded }\end{array}$ & $\begin{array}{l}\text { Double-chain and } \\
\text { seeded }\end{array}$ & $\begin{array}{l}\text { Double-chain and } \\
\text { seeded }\end{array}$ \\
\hline Size of treated area (ha) & 810 & 345 & 292 & 492 & 30 \\
\hline Grazing animal & Cattle & Cattle & Cattle & Sheep & None \\
\hline $\begin{array}{l}\text { Stocking rate } \\
\text { (ha/animal unit) }\end{array}$ & $1978-81=1.5$ & $\begin{array}{l}1965-79=5.6 \\
1980-81=0\end{array}$ & $\begin{array}{l}1972-78=5.0 \\
1979-81=0\end{array}$ & $1967-81=2.5$ & $1979-81=0$ \\
\hline Length of grazing (days) & 30 & 55 & 45 & 60 & None \\
\hline
\end{tabular}

Table 2. Seeding rate (kg/ha) of the major species seeded at the time of treatment and the relative amount of cover (\% of total ground cover by plants) for these seeded species in 1981 on treated pinyon-juniper ranges in central Utah.

\begin{tabular}{|c|c|c|c|c|c|c|c|c|c|c|}
\hline \multirow[b]{3}{*}{ Seeded species } & \multicolumn{4}{|c|}{$\cdot$} & \multicolumn{2}{|c|}{ Study site } & \multirow{2}{*}{\multicolumn{2}{|c|}{ Nine Mile }} & & \\
\hline & Pic & & May & ield & Corn & reek & & & \multicolumn{2}{|c|}{ Hilltop } \\
\hline & $\begin{array}{c}\text { Rate } \\
(\mathrm{kg} / \mathrm{ha})\end{array}$ & $\begin{array}{c}\text { Rel Cov } \\
(\%)\end{array}$ & $\begin{array}{c}\text { Rate } \\
\text { (kg/ha) }\end{array}$ & $\begin{array}{c}\text { Rel Cov } \\
(\%)\end{array}$ & $\begin{array}{c}\text { Rate } \\
\text { (kg/ha) }\end{array}$ & $\begin{array}{c}\text { Rel Cov } \\
(\%)\end{array}$ & $\begin{array}{c}\text { Rate } \\
(\mathbf{k g} / \mathbf{h a})\end{array}$ & $\begin{array}{c}\text { Rel Cov } \\
(\%)\end{array}$ & $\begin{array}{c}\text { Rate } \\
(\mathrm{kg} / \mathrm{ha})\end{array}$ & $\begin{array}{c}\text { Rel Cov } \\
(\%)\end{array}$ \\
\hline $\begin{array}{l}\text { Agropyron cristatum } \\
\text { Agropyron intermediu } \\
\text { Bromus inermis } \\
\text { Elymus junceus }\end{array}$ & $\begin{array}{r}1.6 \\
.5\end{array}$ & $\begin{array}{c}3.1 \mathrm{a}^{1} \\
.2^{2}\end{array}$ & $\begin{array}{r}2.4 \\
.6 \\
2.3 \\
1.2\end{array}$ & $\begin{array}{c}21.8 \mathrm{ab} \\
1.0 \\
10.6 \mathrm{~b} \\
5.1\end{array}$ & $\begin{array}{l}4.7 \\
1.9 \\
1.2 \\
1.1\end{array}$ & $\begin{array}{c}28.3 b \\
5.1\end{array}$ & $\begin{array}{l}6.2 \\
3.1 \\
2.1 \\
2.0\end{array}$ & $\begin{array}{c}17.8 \mathrm{ab} \\
5.9 \\
.3 \mathrm{a} \\
3.1\end{array}$ & $\begin{array}{r}1.8 \\
.9 \\
.9\end{array}$ & $\begin{array}{l}4.4 a \\
6.0\end{array}$ \\
\hline $\begin{array}{l}\text { Medicago sativa } \\
\text { Melilotus officinale } \\
\text { Sanguisorba minor }\end{array}$ & .1 & & $\begin{array}{r}1.8 \\
1.2 \\
.6\end{array}$ & & $\begin{array}{l}.8 \\
.4 \\
.4\end{array}$ & .1 & $\begin{array}{r}1.0 \\
.6 \\
.5\end{array}$ & .2 & $\begin{array}{r}2.7 \\
.9 \\
.9\end{array}$ & $\begin{array}{r}.9 \\
1.4 \\
2.5\end{array}$ \\
\hline $\begin{array}{l}\text { Artemisia tridentata } \\
\text { Artemisia nova } \\
\text { Atriplex canescens } \\
\text { Chrysothamnus nauseosus } \\
\text { Cowania stansburiana } \\
\text { Purshia tridentata }\end{array}$ & $\begin{array}{l}.1 \\
.2 \\
.1 \\
.1 \\
.3\end{array}$ & $31.8 \mathrm{a}$ & $\begin{array}{l}.6 \\
.1 \\
.1 \\
.1\end{array}$ & $\begin{array}{c}1.2 b \\
16.1 b \\
.1\end{array}$ & $\begin{array}{r}.4 \\
.1 \\
1.1 \\
.4 \\
.1 \\
.1\end{array}$ & $\begin{array}{r}17.1 \mathrm{ab} \\
\\
15.0 \\
.1\end{array}$ & $\begin{array}{l}.5 \\
.1 \\
.7 \\
.6 \\
.1 \\
.1\end{array}$ & $\begin{array}{c}1.5 b \\
4.1 \mathrm{a} \\
.2 \\
.2 \\
.1\end{array}$ & $\begin{array}{l}.9 \\
.9 \\
.5 \\
.2 \\
.2\end{array}$ & \\
\hline $\begin{array}{l}\text { Totals }^{3} \\
\text { Seeded grasses } \\
\text { Seeded forbs } \\
\text { Seeded shrubs }\end{array}$ & $\begin{array}{r}2.6 \\
.1 \\
.8\end{array}$ & $\begin{array}{r}3.9 b \\
47.6 \mathrm{a}\end{array}$ & $\begin{array}{r}7.0 \\
3.6 \\
.8\end{array}$ & $\begin{array}{l}50.2 \mathrm{a} \\
22.1 \mathrm{ab}\end{array}$ & $\begin{array}{l}9.7 \\
2.0 \\
2.3\end{array}$ & $\begin{array}{l}33.9 \mathrm{ab} \\
.1 \\
32.2 \mathrm{ab}\end{array}$ & $\begin{array}{r}14.3 \\
1.5 \\
1.9\end{array}$ & $\begin{array}{c}27.1 \mathrm{ab} \\
.3 \\
6.0 \mathrm{~b}\end{array}$ & $\begin{array}{l}3.6 \\
5.0 \\
2.9\end{array}$ & $\begin{array}{c}10.5 \mathrm{ab} \\
4.8\end{array}$ \\
\hline Total of seeded species ${ }^{3}$ & 3.5 & $51.5 \mathrm{a}$ & 11.4 & $72.3 a$ & 14.0 & $66.2 \mathrm{a}$ & 17.7 & $33.4 \mathrm{ab}$ & 11.4 & $15.3 b$ \\
\hline
\end{tabular}

ICover values for each species across sites with the same letter are not significantly different at $p<0.05$.

${ }^{2}$ Where no letter appears, the cover values for that species are not significantly different.

${ }^{3}$ Totals include other seeded species which were seeded $(<0.1 \mathrm{~kg} / \mathrm{ha})$.

Table 3. Total plant cover (\% ground cover by all plants) and relative cover (\% of total plant cover) by different plant life forms on untreated (Unt) and treated (Trt) big game ranges in central Utah.

\begin{tabular}{|c|c|c|c|c|c|c|c|c|c|c|}
\hline \multirow[b]{3}{*}{ Characteristic } & \multicolumn{10}{|c|}{ Study site } \\
\hline & \multicolumn{2}{|c|}{ Pioneer } & \multicolumn{2}{|c|}{ Mayfield } & \multicolumn{2}{|c|}{ Corn Creek } & \multicolumn{2}{|c|}{ Nine Mile } & \multicolumn{2}{|c|}{ Hilltop } \\
\hline & Unt & Trt & Unt & Trt & Unt & $\mathrm{Trt}$ & Unt & Trt & Unt & Trt \\
\hline $\begin{array}{l}\text { Total plant cover } \\
\text { Annuals } \\
\text { Perennial grasses } \\
\text { Perennial forbs } \\
\text { Shrubs } \\
\text { Trees }\end{array}$ & $\begin{array}{c}46 a^{\prime} \\
2 c \\
1 c \\
0 c \\
9 b \\
88 a\end{array}$ & $\begin{array}{r}44 \mathrm{a} \\
6 \mathrm{~b} \\
8 \mathrm{~b} \\
2 \mathrm{~b} \\
43 \mathrm{a} \\
41 \mathrm{~b}\end{array}$ & $\begin{array}{r}36 a \\
0 c \\
4 c \\
2 c \\
11 b \\
81 a\end{array}$ & $\begin{array}{r}29 \mathrm{a} \\
1 \mathrm{~b} \\
54 \mathrm{a} \\
4 \mathrm{~b} \\
29 \mathrm{a} \\
12 \mathrm{~b}\end{array}$ & $\begin{array}{l}21 \mathrm{ab} \\
5 \mathrm{c} \\
5 \mathrm{c} \\
2 \mathrm{c} \\
14 \mathrm{~b} \\
74 \mathrm{a}\end{array}$ & $\begin{array}{l}30 \mathrm{a} \\
10 \mathrm{~b} \\
36 \mathrm{ab} \\
3 \mathrm{~b} \\
38 \mathrm{a} \\
13 \mathrm{~b}\end{array}$ & $\begin{array}{r}24 a \\
2 c \\
4 c \\
0 c \\
1 b \\
93 a\end{array}$ & $\begin{array}{c}17 a b \\
8 b \\
33 a b \\
2 b \\
19 a \\
38 b\end{array}$ & $\begin{array}{r}28 \mathrm{a} \\
2 \mathrm{c} \\
1 \mathrm{c} \\
1 \mathrm{c} \\
1 \mathrm{~b} \\
95 \mathrm{a}\end{array}$ & $\begin{array}{c}15 b \\
34 a \\
19 a b \\
35 a \\
9 a \\
3 b\end{array}$ \\
\hline
\end{tabular}

'Values for each characteristic across sites with the same letter are not significantly different at $p<0.05$. 
Table 4. Soll characteriatics on untreated (Unt) and treated (Trt) pinyon-juniper ranges in central Utah. All nutrient concentrations except $N$ are reported in $\mathbf{m g} / \mathbf{k g}$.

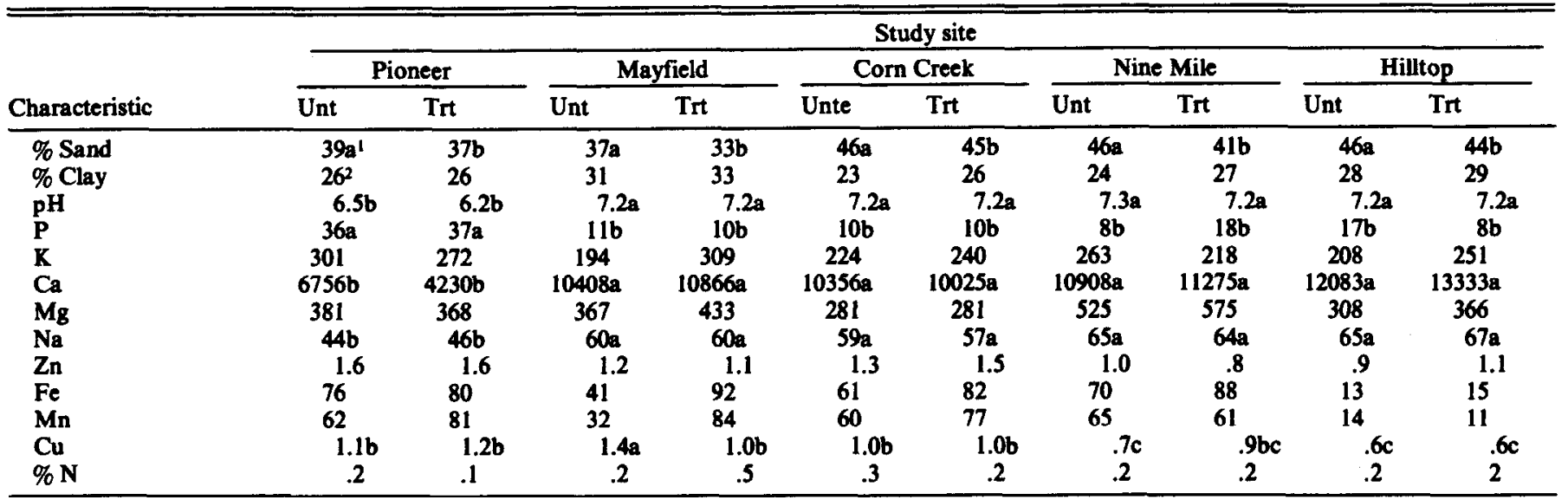

iMean values across sites with the same letter are not significantly different at $p<0.05$.

2Where no letters appear, the values for that nutrient across sites are not significantly different.

on all treated sites and was most prevalent on intermediate-aged sites. Intermediate wheatgrass (Agropyron intermedium (Host) Beauv.) also established and persisted on these sites. Smooth brome (Bromus inermis Leyss.) and Russian wildrye (Elymus junceus Fisch.) established and persisted on the Mayfield and Nine Mile sites. Alfalfa (Medicago sativa L.), yellow sweetclover (Melilotus officinale (1.) Lamb.), and small burnet (Sanguisorba minor Scop.), all biennial or perennial forbs, were present in the greatest amounts on the 2-year-old treated site. These species have been known to persist and maintain themselves after seeding (Plummer et al. 1968), but they were found only in scarce amounts on the 14-year-old sites (Table 2).

Soil analysis revealed several significant differences between soils of untreated and treated areas, and between sites (Table 4). Sand content was significantly lower on treated compared to untreated areas. Soils at Pioneer were lower in $\mathrm{pH}$ and $\mathrm{Ca}$, and higher in $\mathrm{P}$ than the other sites. A soil $\mathrm{pH}$ of 6.5 on this site may have released greater amounts of $P$ and $K$ for plant uptake. These 2 nutrients have been shown to be limiting to juniper growth (Bunderson et al. 1985). Differences in texture and other nutrients showed no specific trends and were not consistent with any particular vegetation characteristic (Leonard et al. 1987).

\section{Woody Plant Density}

Juniper density after treatment was significantly lower on only 2 of the 5 sites (Table 5) (Rippel et al. 1983). Pinyon density was reduced by treatment on 2 out of 3 sites where it was found. Gambel oak, a prolific root sprouter, can spread after mechanical treatment. Gambel oak response to mechanical treatment varied across our sites.

Shrub density was significantly higher on 4 out of 5 sites with density increases from 2 to 10 times on treated sites when compared to untreated areas (Table 5). In this study, artificial seeding of shrubs was only successful on sites where the shrub species was already present in the understory naturally. Some shrub species are better adapted to the soils and climate of particular sites (Plummer et al. 1968). Seeding of nonnative shrub seed did not produce stands. Broom snakeweed density probably increased on the treated areas because it is a weedy invader shrub adapted to disturbed sites (Arnold et al. 1964).

\section{Pinyon-Juniper Stand Relations}

Mature tree canopies attenuate from 50 to $90 \%$ of the light that reaches the outside of the crown, which in turn reduces the light available to the understory (Larcher 1980). Large trees also monopolize basic resources (such as soil moisture and nutrients)

Table 5. Dendity (plants/ha) of woody plant species on untreated (Unt) and treated (Trt) pinyon-juniper ranges in central Utah.

\begin{tabular}{|c|c|c|c|c|c|c|c|c|c|c|}
\hline \multirow[b]{3}{*}{ Characteristic } & \multicolumn{10}{|c|}{ Study site } \\
\hline & \multicolumn{2}{|c|}{ Pioneer } & \multicolumn{2}{|c|}{ Mayfield } & \multicolumn{2}{|c|}{ Corn Creek } & \multicolumn{2}{|c|}{ Nine Mile } & \multicolumn{2}{|c|}{ Hilltop } \\
\hline & Unt & Trt & Unt & Trt & Unte & Trt & Unt & Trt & Unt & Trt \\
\hline $\begin{array}{l}\text { Trees } \\
\text { Juniperus osteosperma } \\
\text { Pinus edulis } \\
\text { Quercus gambelii } \\
\text { Total }\end{array}$ & $\begin{array}{l}771 \mathrm{a}^{1} \\
2660 \mathrm{a} \\
3431 \mathrm{a}\end{array}$ & $\begin{array}{l}405 b c \\
1079 a b \\
1484 b\end{array}$ & $\begin{array}{c}442 b c \\
503 a \\
389 b \\
1358 b\end{array}$ & $\begin{array}{c}276 c \\
121 b \\
1039 a b \\
1436 b\end{array}$ & $\begin{array}{r}852 a \\
\\
369 b \\
1221 b\end{array}$ & $\begin{array}{r}973 a \\
49 b \\
1022 b\end{array}$ & $\begin{array}{c}\text { 678ab } \\
606 \mathrm{a} \\
768 \mathrm{ab} \\
2052 \mathrm{ab}\end{array}$ & $\begin{array}{l}569 a b \\
352 a \\
280 b \\
1201 b\end{array}$ & $\begin{array}{l}586 a b \\
149 b \\
139 b \\
874 b\end{array}$ & $\begin{array}{r}129 c \\
10 c \\
9 b \\
148 b\end{array}$ \\
\hline $\begin{array}{l}\text { Shrubs } \\
\text { Artemisia tridentata } \\
\text { Artemisia nova } \\
\text { Cercocarpus montanus } \\
\text { Chrysothamnus nauseosus } \\
\text { Cowania stansburiana } \\
\text { Purshia tridentata } \\
\text { Gutierrezia sarothrae } \\
\text { Total }\end{array}$ & $\begin{array}{r}02 \\
108 b \\
389 c \\
1848 b\end{array}$ & $\begin{array}{c}14 \\
533 a \\
1371 b \\
3957 a\end{array}$ & $\begin{array}{r}0 c \\
99 a \\
575\end{array}$ & $\begin{array}{c}132 c \\
1027 b \\
332\end{array}$ & $\begin{array}{c}149 b \\
78 \\
85 c \\
617 c\end{array}$ & $\begin{array}{c}334 \mathrm{a} \\
28 \\
931 \mathrm{~b} \\
2898 \mathrm{a}\end{array}$ & $\begin{array}{c}253 \mathrm{bc} \\
135 b \\
9 \\
0 \\
99 c \\
496 c\end{array}$ & $\begin{array}{c}244 \mathrm{bc} \\
768 \mathrm{a} \\
54 \\
9 \\
3380 \mathrm{a} \\
4455 \mathrm{a}\end{array}$ & $\begin{array}{l}268 c \\
298 c\end{array}$ & $\begin{array}{l}477 \mathrm{~b} \\
586 \mathrm{c}\end{array}$ \\
\hline
\end{tabular}

IValues within species across sites with the same letter are not significantly different at $p<0.05$.

2Where no letters appear, the density values for that species across sites are not significantly different. 


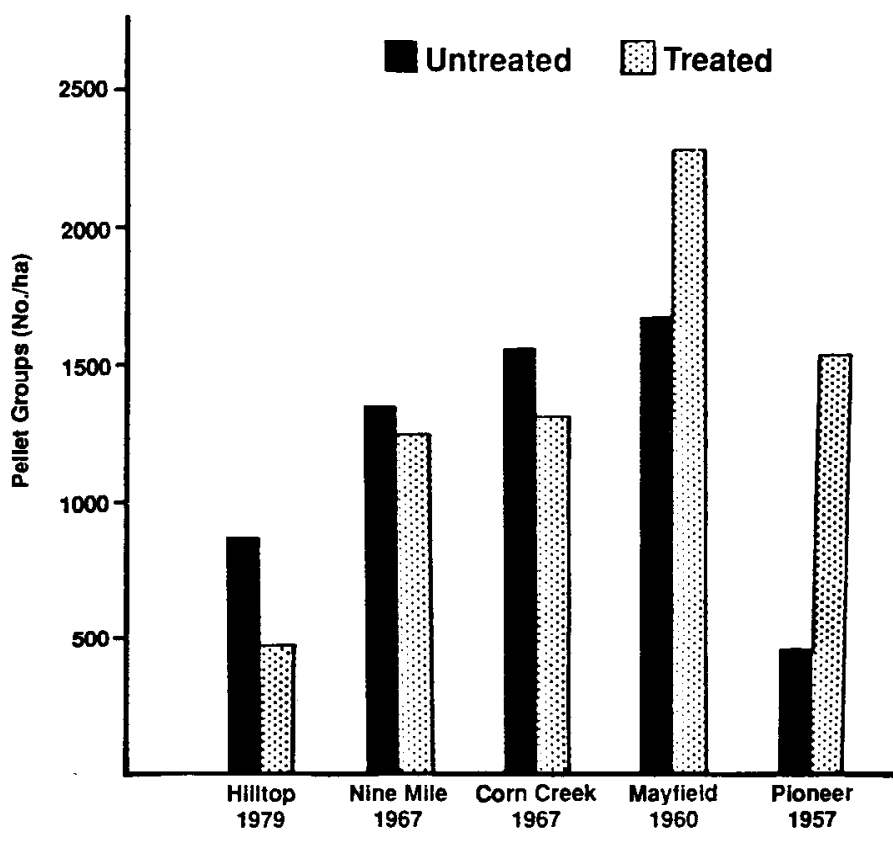

Fig. 2. Pellet groups (No./ha) on untreated and treated pinyon-juniper big game ranges in central Utah.

the distance into the treated area increased up to $150 \mathrm{~m}$. Some researchers report that big game use of treated pinyon-juniper sites increased due to greater amounts of forage and browse on the treated area, and their pellet group data support this finding (Minnich 1969, McCulloch 1969, Plummer et al. 1966). Others indicate that treatment has reduced security cover to the extent that big game use declined (Lyon and Jensen 1980, Short et al. 1977, Terrel and Spillett 1975). Phillips (1977) states that young pinyon-juniper chaining projects contribute little to big game until shrubs and trees become established within the treated area (see also Short and McCulloch 1977). Other reports, such as this study, show both higher and lower pellet group densities on treated sites when compared to adjacent untreated areas (Howard et al. 1987, Payne 1981, Phillips 1977). Our experience and research on Utah big game range has shown that big game utilize treated areas as much or more than untreated areas; and, perhaps more importantly, big game use of these treated areas during critical times of the year (i.e., late fall, winter, and early spring) is extended. Because greater amounts of herbs, grasses, and browse are available on treated sites, big game use is enhanced and increases with time as browse and tree species develop in the site.

\section{Literature Cited}

Arnold, J.F., D.A. Jameson, and E.H. Reid. 1964. The pinyon-juniper type of Arizona; Effects of grazing, fire and tree control. USDA Forest Serv. Prod. Res. Rep. RM-84.

Aro, R.S. 1971. Evaluation of pinyon-juniper conversion to grassland. J. Range Manage. 24:188-197.

Aro, R.S. 1975. Pinyon-juniper woodland manipulations with mechanical methods, p. 67-76. In: The Pinyon-Juniper Ecosystem: A Symposium. Utah State Univ., Logan.

Barney, M.A., and N.C. Frischknecht. 1974. Vegetation changes following fire in the pinyon-juniper type of west central Utah. J. Range Manage. 17:91-94.

Black, C.A. 1965. Methods of soil analysis. Chemical and microbiological properties. Agron. Monog. 9. Amer. Soc. Agron., Madison, Wis.

Bunderson, E.D., D.J. Weber, and J.N. Davis. 1985. Soil mineral composition and nutrient uptake in Juniperus osteosperma in $17 \mathrm{Utah}$ sites. Soil Sci. 139:139-148.
Bunting, S.C. 1987. Use of prescribed burning in juniper and pinyonjuniper woodlands, p. 141-144. In: R.L. Everett (ed.). Proc.-Pinyonjuniper conference. USDA Forest Serv. Gen. Tech. Rep. INT-215.

Collins, W.B., and P.J. Urness. 1981. Habitat preferences of mule deer as rated by pellet-group distributions. J. Wildl. Manage. 45:969-972.

Daubenmire, R. 1959. A canopy-coverage method of vegetational analysis. Northwest Sci. 33:43-46.

Ferguson, R.B. 1955. The weathering and persistency of pellet groups as it affects the pellet group count method of censusing mule deer. Utah Acad. Sci., Arts, and Letters 32:59-64.

Grime, J.P. 1979. Plant strategies and vegetation processes. John Wiley and Sons, New York.

Howard, V.W., Jr., K.M. Cheap, R.H. Hier, T.G. Thompson, and J.A. Dimas. 1987. Effects of cabling pinyon-juniper on mule deer and lagomorph use, p. 552-557. In: R.L. Everett (ed.). Proc.-Pinyon-juniper conference. USDA Forest Serv. Gen. Tech. Rep. INT-215.

Johnsen, T.M., Jr. 1987. Using herbicides for pinyon-juniper control in the Southwest, p. 330-334. In: R.L. Everett (ed.). Proc.-Pinyon-juniper conference. USDA Forest Serv. Gen. Tech. Rep. INT-215.

Kuchler, A.W. 1964. Potential vegetation in the conterminous United States. Amer. Geogr. Soc. Spec. Pub. 36.

Larcher, W. 1980. Physiological plant ecology. Second Edition. SpringerVerlag, New York.

Leonard, S.G., R.L. Miles, and H.A. Summerfield. 1987. Soils of the pinyon-juniper woodlands, p. 227-230. In: R.L. Everett (ed.). Proc. -Pinyon-juniper conference. USDA Forest Serv. Gen. Tech. Rep. INT-215.

Lyon, L.J., and C.E. Jensen. 1980. Management implications of elk and deer use of clear-cuts in Montana. J. Wildl. Manage. 44:352-361.

McCulloch, C.Y. 1969. Some effects of wildfire on deer habitat in pinyonjuniper woodland. J. Wildl. Manage. 33:778-784.

Minnich, D.W. 1969. Vegetative response and pattern of deer use following chaining of pinyon and juniper forest. Colorado Div. Game and Fish and Parks, Denver.

Neff, D.K. 1968. The pellet-group count technique for big game trend, census, and distribution: a review. J. Wildl. Manage. 32:507-532.

O'Rourke, J.T., and P.R. Ogden. 1969. Vegetative response following pinyon-juniper control in Arizona. J. Range Manage. 22:416-418.

Parker, R.D. 1971. A study of the effects of two conversion treatments on pinyon-juniper revegetation in Utah. Ph.D. Diss., Brigham Young Univ., Provo, Utah.

Payne, J.F. 1981. A multi-site evaluation of pinyon-juniper chaining in Utah. M.S. Thesis. Utah State Univ., Logan.

Phillips, T.A. 1977. An analysis of some Forest Service pinyon-juniper chaining projects in Region 4-1954-1975. Range Imp. Notes. USDA Forest Serv. Int. Reg., Ogden, Utah.

Plummer, A.P. 1958. Restoration of pinyon-juniper ranges in Utah, p. 207-211. In: Proc. Amer. Soc. Forest., Salt Lake City, Utah.

Plummer, A.P., D.R. Christensen, and S.B. Monsen. 1968. Restoring big game range in Utah. Utah Div. of Fish and Game, Pub. No. 68-3.

Plummer, A.P., D.R. Christensen, R. Stevens, and K.R. Jorgensen. 1970. Highlights, results and accomplishments of game range restoration studies. Utah State Div. of Fish and Game, Pub. No. 70-3.

Plummer, A.P., S.B. Monsen, and D.L. Christensen. 1966. Game forage restoration. Range Imp. Notes. USDA Forest Serv. Int. Region, Ogden, Utah.

Plummer, A.P., H.D. Stapley, and D.R. Christensen. 1960. Job completion report for game forage revegetation project W-82-R-5. Utah State Dept. of Fish and Game Info. Bull. 1957-1960.

Rippel, R., R.D. Pieper, and G.A. Lymberg. 1983. Vegetational evaluation of pinyon-juniper cabling in south-central New Mexico. J. Range Manage. 36:13-15.

Short, H.L., W. Evans, and E.L. Boeker. 1977. The use of natural and modified pinyon pine-juniper woodlands by deer and elk. J. Wildl. Manage. 41:543-559.

Short, H.L., and C.Y. McCulloch. 1977. Managing pinyon-juniper for wild life. USDA Forest Serv. Gen. Tech. Rep. RM-47.

Steel, R.G.D., and J.H. Torrie. 1980. Principles and procedures of statistics. Second Edition. McGraw-Hill Book Co. New York.

Stevens, R. 1987. Thirty years of pinyon-juniper big game habitat improvement projects: what have we learned? p. 558-571. In: R.L. Everett (ed.). Proc.-Pinyon-juniper conference. USDA Forest Serv. Gen. Tech. Rep. INT-215.

Stevens, R., B.C. Guinta, and A.P. Plummer. 1975. Some aspects in the biological control of juniper and pinyon, p. 77-80. In: The PinyonJuniper Ecosystem: A Symposium. Utah State Univ., Logan. 
Tausch, R.J. 1973. Plant succession and mule deer utilization on pinyonjuniper chainings in Nevada. M.S. Thesis, Univ. of Nevada, Reno, Nev. Tuusch, R.J., and P.T. Tueller. 1977. Plant succession following chaining of pinyon-juniper woodlands in eastern Nevada. J. Range Manage. 30:44-49.
Terrel, T.L., and J.J. Spillett. 1975. Pinyon-juniper conversion: its impact on mule deer and other wildlife, p. 105-119. In: The Pinyon-Juniper Ecosystem: A Symposium. Utah State Univ., Logan, Utah.

West, N.E., K.H. Rea, and R.J. Tausch. 1975. Basic synecological relationships in pinyon-juniper woodlands, p. 41-54. In: The PinyonJuniper Ecosystem: A Symposium. Utah State Univ., Logan. 